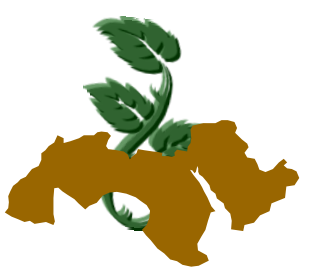

\title{
CHEMICAL CONTROL OF ANNUAL RYEGRASS GROWING WITH BARLEY DURING PRE-EMERGENCE STAGE BY METHABENZTHIAZURON, ISOPROTORON AND CHLOROTOLURON
}

\author{
Khalid S. Alshallash ${ }^{1}$ \\ 1- College of Science and humanities studies, Shagra University, Saudi Arabia \\ (Email: kalshallash@su.edu.sa)
}

Keywords: Rye grass, Growing with barley, Methabenzthiazuron, Isoprotoron and ChlorotoIuron

\begin{abstract}
Treatments by three herbicides named; Methabenzthiazuron, Isoprotoron and ChlorotoIuron to control Italian ryegrass growing with barley during pre-emergence stage were investigated. Results showed that clear damage have been occurred by the three chemicals without prominent effect on barley plants. Italian ryegrass was controlled significantly $(p<0.01)$ by all of the herbicides used but the three herbicides differed significantly $(p<0.05)$ in their effects. Chlorotoluron gave effective control of Lolium multiflorum at dose of $2 \mathrm{~kg}$ a.i/ha and slight damage on barley was observed. Isoproturon and methabenzthiazuron were less effective as more than $40 \%$ of Lolium multiflorum survived at different doses while barley was not affected significantly.
\end{abstract}

\section{INTRODUCTION}

Barley is one of the oldest cultivated cereal grains in the world (Baik \& Ullrich, 2008). Barley, a founder crop of old World Neolithic food production and one of the earliest domesticated crops (Zohary \& Hopf, 2000 and Zohary et al 2012). Weeds can be controlled by manual hoeing, mechanically and by chemical methods. Manual weeding is labor intensive and possible only on small scale. While mechanical weed control is possible in row cropping and leaves intra row weeds.
Herbicides offer the most practical, effective and economical means of reducing early weed competition and crop production losses (Royal Society of Chemistry, 1991; Worthing, 1991. Troxler et al 2002; Brecke and Stephenson, 2006). Methabenzthiazur 1-(1,3-Benzothiazol-2-yl)-1,3dimethylharnstoffon is used for the control of a spectrum of grasses in cereals, legumes, maize, garlic and onions. Madhun \& Freed, 1978. Chlorotoluron 3-(3-chloro-p-tolyl)-1,1-dimethylurea is a pre- or early post-emergence herbicide widely used to control annual grasses and broad-leaved weeds in winter cereals Chandurkar, et al 1990. Isoprotoron 3-(4-isopropylphenyl)-1,1-dimethylurea; 3-p-cumenyl-1,1-dimethylurea is a selective systemic herbicide used as Pre- and post-emergence control of annual grasses (Spliid, and Køppen, 1998).

\section{MATERIALS AND METHODS}

Methabenzthiazuron, Isoprotoron and Chlorotoluron were applied as pre-emergence treatments to $10 \mathrm{~cm}^{2}$ pots with 50 seeds of Lolium multiflorum sown on the surface and 10 seeds of barley planted $2 \mathrm{~cm}$ deep in John James No. 1 compost. The three herbicides were applied at five different doses; methabenzthiazuron at $(0,1,1.5,2,3 \mathrm{~kg}$ a.i.ha-1; Isoproturon at $0,0.5,1,1.25,1.5 \mathrm{~kg}$ a.i.ha$\left.{ }^{1}\right)$ and chlorotoluron at ( $0,1.5,2,2.5,3 \mathrm{~kg}$ a.i.ha- $\left.{ }^{-1}\right)$. Triplect sets were mused for each treatment. Treatments were applied three days after planting, Observations were taken 2 weeks later by counting 
the number of plants and fresh weight /20 plants for both ryegrass and barley.

\section{RESULTS AND DISCUSSION}

While others report good crop safety in wheat. Italian ryegrass was controlled significantly $(p<0.01)$ by all of the herbicides used but the three herbicides differed significantly $(p<0.05)$ in their effects Reports of clear damage from these chemicals have been made (Kasasian, 1977; Fleck and Paulitsch, 1978).

Chlorotoluron gave effective control of Lolium multiflorum at dose of $2 \mathrm{~kg}$ a.i/ha and slight damage on barley was observed (Figs. 1- 2). Isoproturon and methabenzthiazuron were less effective as more than $40 \%$ of Lolium multiflorum survived at different doses (Figs. 3-6). Barley was not affected significantly. Moreover, reports of clear damage from these chemicals have been made by (Kasasian, 1977 and Fleck \& Paulitsch, 1978).

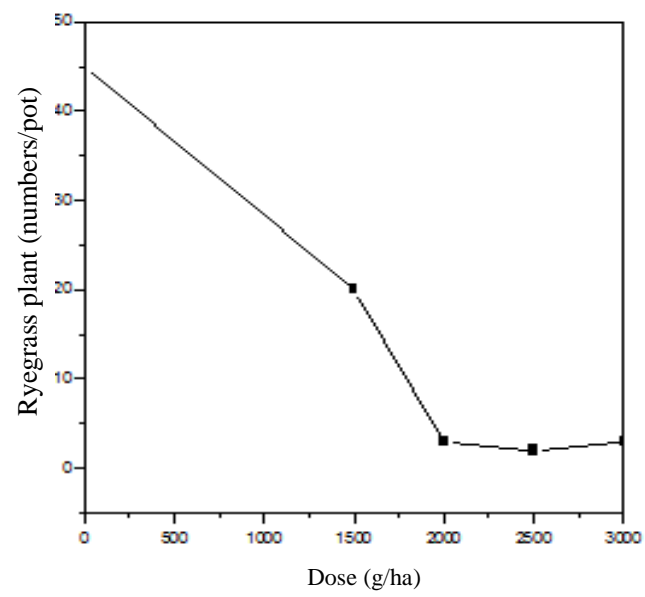

Fig. 1. Effect of Chlorotoluron on annual ryegrass plants (numbers /pot)

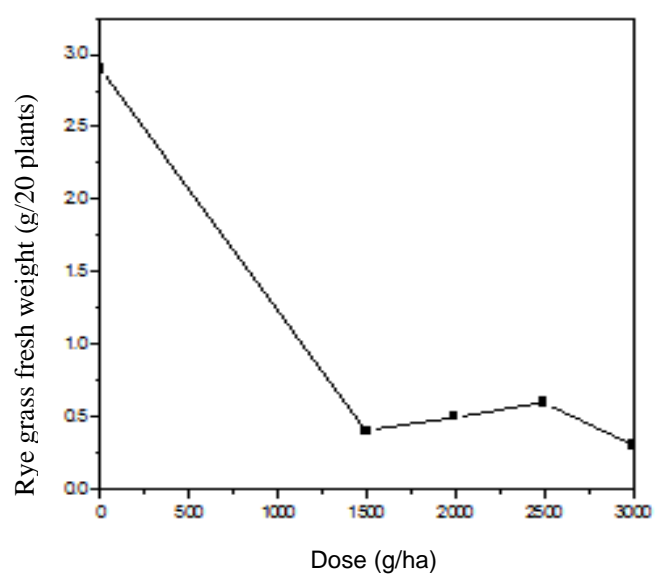

Fig. 2. Effect of Chlorotoluron on annual ryegrass fresh weight ( $\mathrm{g} / 20$ plants)

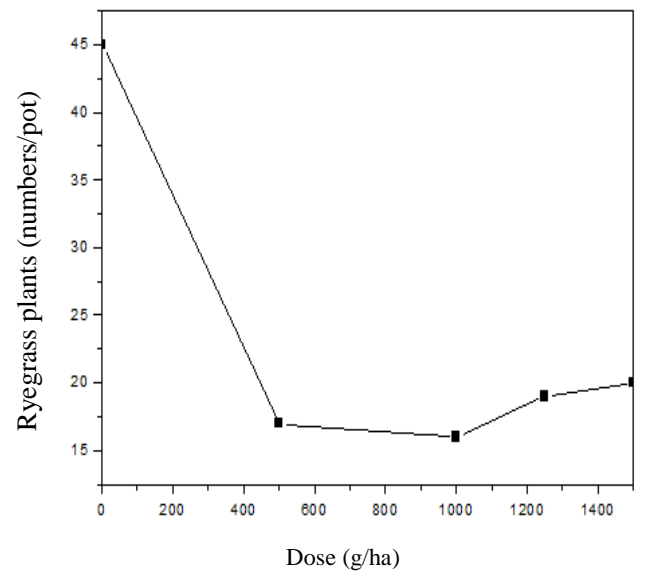

Fig. 3. Effect of Isoproturon on annual ryegrass plants (numbers /pot)

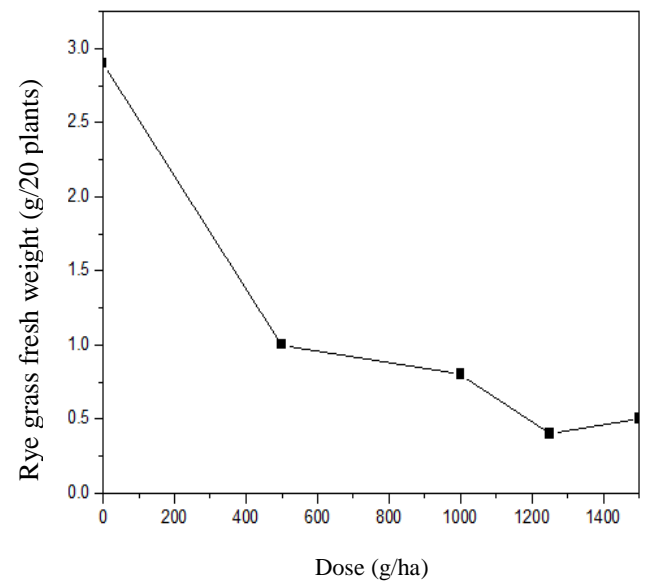

Fig. 4. Effect of Isoproturon on annual ryegrass fresh weight ( $g / 20$ plants)

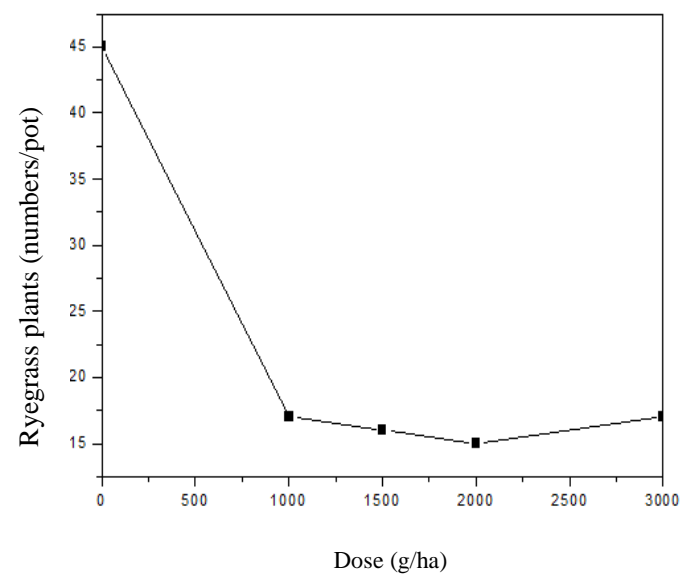


Fig. 5. Effect of Methabenzthiazuron on annual ryegrass plants (numbers /pot)

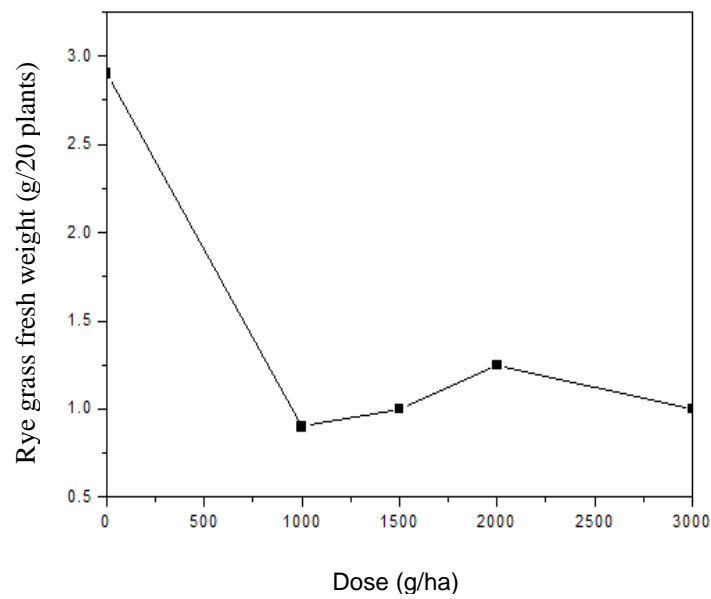

Fig. 6. Effect of Methabenzthiazuron on annual ryegrass fresh weight ( $\mathrm{g} / 20$ plants)

\section{REFERENCES}

Baik, B.K. and Ullrich, S.E. 2008. Barley for food: characteristics improvement and renewed interest. J. Cereal Sci., 48: 233-242.

Brecke, B.J. and Stephenson, D.O. 2006. Weed control in cotton (Gossypium hirsutum L.) with postemergence applications of trifloxysulfuronsodium. Weed Technol., 20(2): 377-383.

Chandurkar, P.S., Cheng, E.Y. and Menzer, R.E. 1990. Metabolism of N-[3-chloro-4-(beta-Dglucosylmethyl) phenyl] urea, a metabolite of chlorotoluron, in rat and Japanese quail. $\mathbf{J}$. Agric. Food Chem., 38: 1739-1742.
Fleck, N.G. and Paulitsch, R.J. 1984. Chemical control of ryegrass (Lolium multiflorum L.) in weaht. Planta Daninha, 1(2): 30-37.

Kasasian, L. 1977. Chemical control in winter cereals at the Hofuf Agricultral Research Center. Saudi Arabia. In Jaunt Agricultural Research and Development Project No. 111.

Madhun, Y.A. and Freed, V.H. 1987. Degradation of the herbicides bromacil, diuron and chlortoluron in soil. Chemosphere, 16(5):1003-1011.

Plumier, W. and Vulsteke, G. 1988. J. Agric. Food Chem., 36: 642-645.

Royal Society of Chemistry 1991. The AgroChemicals Handbook, $3^{\text {rd }}$ ed. Cambridge. pp. 125-210.

Spliid, N.H. and Køppen, B. 1998. Occurrence of pesticides in Danish shallow ground water. Chemosphere 37:1307-1316.

Troxler, S.C., Askew, S.D., Wilcut, J.W., Smith, W.D. and Paulsgrove, M.D. 2002. Clomazone, fomesafen, and bromoxynil systems for bromoxynil resistant cotton (Gossypium hirsutum). Weed Technol. 16: 838-844.

Worthing, C.R. 1991. The Pesticide Manual, $\mathbf{9}^{\text {th }}$ ed. Farnham, British Crop Protection Council. pp. 15-17.

Zohary, D. and Hopf, M. 2000. Domestication of plants in the Old World. $3^{\text {rd }}$ ed. Oxford: Oxford University Press. pp. 110-120.

Zohary, D., Hopf, M. and Weiss, E. 2012. Domestication of Plants in the Old World: The origin and spread of domesticated plants in Southwest Asia, Europe, and the Mediterranean Ba$\sin .4^{\text {th }}$ ed. Oxford: Oxford University Press. pp. 21-40. 